\title{
Evaluation of a Warning System for Early-Season Control of Grapevine Powdery Mildew
}

Tito Caffi, Sara E. Legler, and Vittorio Rossi, Università Cattolica del Sacro Cuore, Institute of Entomology and Plant Pathology, I29122 Via E. Parmense 84, Piacenza, Italy; and Riccardo Bugiani, Plant Protection Service, Regione Emilia-Romagna, Bologna, Italy

\begin{abstract}
Caffi, T., Legler, S. E., Rossi, V., and Bugiani, R. 2012. Evaluation of a warning system for early-season control of grapevine powdery mildew. Plant Dis. 96:104-110.

In several grape-growing areas of the world, including northern Italy, powdery mildew epidemics, caused by Erysiphe necator, are mainly triggered by the ascospores produced in overwintered chasmothecia. Growers in northern Italy usually control the disease with fixed-interval fungicide applications. A warning system was developed for earlyseason powdery mildew control based on (i) short-term weather forecasts, (ii) a model that simulates the severity of each E. necator ascosporic infection, and (iii) a mobile phone short-message system. This warning system was evaluated in six vineyards in northern Italy from 2006 to 2008, between bud break of vines and early berry develop-

ment; an unsprayed control was compared with "low-risk" and "highrisk" model-driven sprays and a calendar-based "grower" spray program. Use of the warning system reduced disease severity on leaves and bunches compared with the unsprayed control and resulted in the same level of control of powdery mildew as the grower's spray program, with reduced fungicide applications and costs. On average, 5.7 sprays were applied following the grower's spray program (with an average cost of $221 € /$ ha/year); use of the warning system reduced fungicide applications by $36 \%$ (low-risk program, saving of 56 $€ /$ ha/year) or $75 \%$ (high-risk program, saving of $161 € /$ ha/year).
\end{abstract}

Powdery mildew of grapevine, caused by Erysiphe necator Schwein. (syn. Uncinula necator (Schwein.) Burrill), is a major disease throughout the world's grape-growing areas. The fungus can infect all green tissues of grapevines and can cause severe damage to leaves and berries. Powdery mildew often causes substantial reductions in crop yield and wine quality $(5,19,39)$. Grape powdery mildew epidemics can progress rapidly over the entire growing season through a recurrence of primary (sexual) and secondary (asexual) infections. In spring, ascospores are repeatedly discharged from the overwintered chasmothecia (41) and cause discrete small spots on the abaxial surfaces of the basal leaves of shoots. Once these initial colonies are established, the fungus can asexually propagate via large numbers of conidia that disperse and infect additional leaves (9). Leaf epidemics serve as a source of inoculum for infection of flowers and developing berries (6). Flag shoots that develop from infected dormant buds can also act as sources of primary inoculum but they are usually absent in the commercial vineyards of northern Italy and other viticultural regions $(13,16,23,26,27,38)$.

Growers typically control the disease by fixed-interval applications of foliar fungicides, with several fungicide sprays applied each growing season, or by using a growth-stage-based fungicide spray program (15). Periodic fungicide applications frequently lead to unjustified sprays, whereas applications based on growth stage do not account for current conditions and also lead to the application of unjustified sprays or poor timing of sprays. On the other hand, a common error is to delay fungicide application until the disease becomes evident in the vineyard (32). Symptoms do not become evident until several weeks after the disease has been initiated and, at that time, the epidemic is generally well established and control is difficult or impossible $(2,46)$.

Control of powdery mildew could be improved and the number of fungicide applications reduced by applying fungicides when

Corresponding author: V. Rossi, E-mail: vittorio.rossi@ unicatt.it

Accepted for publication 22 August 2011

http://dx.doi.org/10.1094/PDIS-06-11-0484

(C) 2012 The American Phytopathological Society disease levels are low and stopping the epidemics before they reach the exponential phase (32). This could be activated by monitoring the vineyard and weather to detect or predict the occurrence of primary infections (31). With this approach, season-long control of powdery mildew depends on reducing early-season inoculum and subsequent infection (21). When primary infections are controlled until all the ascospores have been discharged, the amount of inoculum available for causing secondary infections is reduced (24).

Weather-driven models have been developed to determine the optimum spray intervals during the secondary inoculum season $(10,11,20,28,45)$. For instance, the use of the University of California (UC) Davis Risk Assessment Model allows growers to stretch spray intervals during times of low to intermediate disease pressure and to shorten intervals when pressure was high; use of this model eliminates two to eight fungicide applications per year and provides improved disease control (21). However, little attention has been paid to developing tools for timing fungicide applications in the early season, which is when powdery mildew epidemics begin. Thomas et al. (48) estimated the risk of ascospore infection based on duration of leaf wetness and temperature from the "Conidial Mills Table" (35). Once infection has occurred, the model switches to the risk assessment phase, which is based entirely on the effect of temperature on the reproductive rate of E. necator. Kast (28) determined the first spray date using a rough indexing of the disease severity for the vine site in the preceding year and the mean of the lowest temperatures in the two previous winters. Based on this information and the date when the "three-leaves-unfolded" development stage occurs in the current season, a time lag is calculated. Gadoury et al. (17) proposed to estimate the number of ascospore infection periods between bud break and flowering under the assumption that an infection occurs in response to a rain of $>2.5 \mathrm{~mm}$ at a temperature $>10^{\circ} \mathrm{C}$. Carisse et al. (8) suggested that managers should scout the vineyard for the first symptoms of disease once suitable environmental conditions had occurred ( $\geq 2.5 \mathrm{~mm}$ of rainfall over a $\geq 4$-h period at 6 to $24^{\circ} \mathrm{C}$ ) and should apply the first spray when the disease was detected.

A weather-driven, mechanistic, and dynamic model for E. necator ascosporic infections on grapevine was recently developed (4). Between bud break of vines and the time when the stock of ascospores is depleted, the model uses weather data for calculating ascospore maturation and discharge, infection periods, and the time 
when secondary infections should begin. This model was validated over a 4-year period in 26 vineyards in Italy by comparing model predictions with actual observations. The model showed high sensitivity, specificity, and accuracy. Proportions of true and false positive predictions were 0.94 and 0.26 , respectively, so that the model provided some unjustified alarms.

The model of Caffi et al. (4) could improve early-season powdery mildew management by helping growers schedule fungicide sprays. Nevertheless, this model has not been thoroughly evaluated in the field to determine whether its predictions of powdery mildew primary infections can be used to manage this disease. Thus, a disease warning system using this model (4) and short-term weather forecasts was developed and is described and evaluated here.

\section{Materials and Methods}

Disease warning system. The warning system includes three components: (i) the weather data, (ii) a powdery mildew prediction model, and (iii) a mobile phone short-message service (SMS). The Agro-Meteorological Service of the Emilia-Romagna Region (http://www.arpa.emr.it/sim/) in northern Italy provided hourly weather data for air temperature $(\mathrm{T})$, relative humidity $(\mathrm{RH})$, rainfall amount (R), and presence of wetness (W) for each node of a 5by-5-km grid that covers the region (37). For each node, data until 24:00 $\mathrm{h}$ of the previous day and weather forecasts for the following $72 \mathrm{~h}$ were used. The regional system provided hourly forecasts of $\mathrm{T}, \mathrm{RH}, \mathrm{R}$, and W for a 72-h time range using the "Consortium for Small-Scale Modelling Limited Area Model Italy" model (47). Data for the nodes corresponding to the geographical coordinates of the experimental vineyards were downloaded from the official web site each morning between 1 April and 30 June and were used for operating the disease model.

The model used in this study (4) predicts the occurrence of powdery mildew infection periods during the primary inoculum season (i.e., between bud break of vines and the time when the stock of ascospores is depleted). The model uses weather data for calculating, at daily intervals, the curve of ascospore maturation, ascospore discharge events and relative proportion of the discharged ascospores, infection periods and their relative severity of infection, and progress of latency period and time when secondary infections should begin. Therefore, the model is able to predict the time when any ascospore discharge results in a powdery mildew infection.

The model was used to determine the beginning and end of the primary inoculum season of E. necator. Within this time period, the model was operated daily using the data until 24:00 $\mathrm{h}$ of the previous day and forecasts for the next $72 \mathrm{~h}$. Therefore, two kinds of model output were obtained daily: calculated infection for the previous day and predicted infection for the current and the following 2 days. Hence, two kinds of alarms were provided: an infection period has already occurred on the previous day, and an infection period is likely to occur on the current day or on the following 2 days. Predicted infection could be confirmed or not confirmed as follows: (i) an infection period was predicted by using the weather forecasts and was confirmed a posteriori by using the actual weather data, (ii) an infection period was predicted but was not confirmed by the actual weather data, and (iii) an infection period was not predicted but was calculated a posteriori using the actual weather data. Possible secondary infections caused by the E. necator conidia were not considered for producing warnings.

For either calculated or predicted infection periods, an SMS was sent to the mobile phone of the managers of the experimental vineyards. Two kinds of SMSs were sent: "a powdery mildew infection period is predicted for the day d" (the current day or one of the 2 following days), and "a not previously predicted infection period occurred on the day d" (usually the previous day). These SMSs were regarded as decision supports for the vineyard managers. Managers of each vineyard decided to spray or not following any alarm on the basis of previous fungicide applications (i.e., no fungicides were applied to control a predicted infection which was already controlled by a previous fungicide spray). Managers also decided the exact time of spraying with respect to the day of any predicted infection based on local weather conditions (particularly the occurrence of rain showers which make entering into the vineyard impossible) and availability of manpower.

Field experiments. Experiments were carried out at three locations in Emilia-Romagna (northern Italy): Castel San (C.S.) Pietro, Tebano, and Pianoro. The C.S. Pietro vineyard ( $44^{\circ} 24^{\prime} 29^{\prime \prime}$ N, $11^{\circ}$ $33^{\prime} 15^{\prime \prime} \mathrm{E}, 60 \mathrm{~m}$ in altitude) contained Vitis vinifera 'Sangiovese' vines that were 10 years old in 2006 and trained with a permanent cordon system with spur pruning. The Tebano vineyard $\left(44^{\circ} 17^{\prime}\right.$ $39^{\prime \prime} \mathrm{N}, 11^{\circ} 47^{\prime} 09^{\prime \prime} \mathrm{E}, 177 \mathrm{~m}$ in altitude) contained V. vinifera 'Pinot noir' vines that were 21 years old in 2006 and trained according to the spurred cordon system. The Pianoro vineyard $\left(44^{\circ} 23^{\prime}\right.$ $14^{\prime \prime} \mathrm{N}, 11^{\circ} 20^{\prime} 36^{\prime \prime} \mathrm{E}, 264 \mathrm{~m}$ in altitude) contained $V$. vinifera 'Chardonnay' vines that were 11 years old in 2006 and trained on a Guyot double-arm system. The within-row and between-row spacing was 1.2 by 3.3 and 1.4 by $3.5 \mathrm{~m}$ for the first two and third vineyard, respectively. All cultivars used in these experiments are susceptible to powdery mildew (43).

The vineyards were managed following standard practices except as indicated for fungicides. Downy mildew was controlled, when necessary, with appropriate fungicides that lack collateral activity on E. necator. For powdery mildew control, the following four treatments were compared: (i) vines were unsprayed (hereafter referred to as "unsprayed"); (ii) vines were sprayed when the warning system predicted an infection period using weather forecasts or calculated an infection period using actual weather data (i.e., a posteriori), and at least 7 days had elapsed since the previous fungicide application (hereafter referred to as the "low-risk" spray program); (iii) vines were sprayed as in treatment ii but only if the ascospore dose that caused infection (either predicted or calculated) represented at least $4 \%$ of the seasonal ascospore dose (hereafter referred to as the "high-risk" spray program); and (iv) vines were sprayed according to the grower's schedule (hereafter referred to as the "grower" spray program). The experiment in each vineyard was set up as a complete randomized block design with four replicate plots; each plot consisted of three rows with at least six plants per row. Six independent field experiments were conducted in total. Experiments were conducted in the Tebano vineyard in 2006, 2007, and 2008; in the C.S. Pietro vineyard in 2007 and 2008; and in the Pianoro vineyard in 2006. For experiments conducted in the same vineyard, entirely different subplots of vines were used in different years to guarantee a representative dose of the E. necator inoculum.

For the low-risk and high-risk spray programs, preventative sprays (i.e., sprays applied within the date signaled in the SMS warning) were made with Spiroxamine or Quinoxyfen (commercial products at 70 and $30 \mathrm{~g} / \mathrm{hl}$ of water, respectively). Curative sprays (i.e., sprays applied after the date recommended by model output) were made with Spiroxamine (at $70 \mathrm{~g} / \mathrm{hl}$ of water). Curative sprays in the low-risk and high-risk spray programs were also applied when an infection period was not predicted using the weather forecast but was calculated a posteriori using the actual data. For the grower spray program, different plant protection products were used (Table 1) according to each grower's schedule (Table 2). All of these products are considered effective for controlling powdery mildew in northern Italy (43) and were used at the label rates.

Table 1. Commercial fungicides and their active ingredients used for the control of powdery mildew of grape in the different spray programs

\begin{tabular}{llll}
\hline Commercial name & Active ingredient & Percent & Producer \\
\hline A, Arius & Quinoxyfen & 22.58 & Dow \\
B, Flint & Trifloxystrobin & 50 & Bayer \\
C, Karathane Star & Meptyldinocap & 35.71 & Dow \\
D, Kumulus Tecno & Sulfur & 80 & BASF \\
E, Prosper 300 CS & Spiroxmine & 30.9 & Bayer \\
F, Tiovit Jet & Sulfur & 80 & Syngenta \\
G, Vivando & Metafrenone & 42.37 & BASF \\
\hline
\end{tabular}


Plant protection products were applied with a knapsack airblast sprayer SR 420 (Stihl Inc., Virginia Beach, VA) with an ultra-lowvolume nozzle which ensured an even distribution on the whole plot. Depending on the trellis system and growth stage of the vines, 4 to $8 \mathrm{hl}$ of water with product were applied per hectare.

Disease assessment. Starting from bud break, the vineyards were inspected at least once a week to determine (i) the prevalent growth stage of vines (i.e., the growth stage reached by $>50 \%$ of vines) based on the modified Eichhorn-Lorenz system (12) and (ii) the time of appearance of the first disease symptoms, such as flag shoots or discrete pale spots on the abaxial surfaces of the basal leaves. Observation of the latter symptoms, which are typically caused by ascosporic infections (41), were carried out for detecting the start of the powdery mildew epidemics and not for further validating the powdery mildew prediction model (4). Flag shoots were never found in the experimental vineyards.

Each growing season, disease severity was assessed three times on a sample of 100 random leaves and one time on 100 bunches per plot, on both sides of the rows between flowering and early berry formation, which is the period of highest susceptibility to $E$. necator infection (18). The leaves were not necessarily the same for the three assessment times. Leaves and bunches were carefully observed for powdery mildew symptoms and classified as healthy or diseased, and disease incidence was calculated as a percentage of affected leaves (or bunches). Disease severity was estimated visually and expressed as a percentage of the total leaf (or bunch) area (7).

Data analysis. Data for disease severity were arcsine transformed to make variances uniform and then subjected to a one-way analysis of variance for a completely randomized block design, with four replicates. A separate analysis was done for each disease assessment time in each experiment. The Fisher's protected least square difference test was used at $P=0.05$ to separate means.

The efficacy of fungicide treatments was determined based on mean disease severity on leaves and bunches with the formula $E=$ $100-[(Y s / Y u) \times 100]$, where $E$ is the efficacy of the treatment, $Y s$ is disease severity in the sprayed leaves or bunches, and $Y u$ is disease severity in the unsprayed control plots.

Spray programs were also compared on the basis of costs directly related to the fungicide applications. The costs, calculated in euros per hectare, included fungicide cost, fuel consumption, and human labor. Costs of the fungicides were Arius and
Karathane Star, $18 € /$ ha; Flint, $21 € /$ ha; Prosper, $28 € /$ ha; Vivando, $17 € /$ ha; and Kumulus and Tiovit, $7 € /$ ha. Fuel consumption was $4.9 € /$ ha per application $(0.8 € /$ liter of fuel, 7 liter/ha per

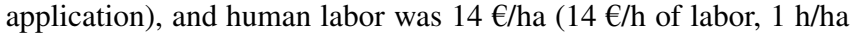
per application). The costs of the warning system were not considered because fixed costs for setting up and maintaining the warning system were paid by the Plant Protection Organisation of the Emilia-Romagna region, which routinely produces free warnings for advisors and growers, and the additional cost for sending SMS messages was small.

\section{Results}

Disease alarms. Examples of disease warnings are presented in Figures 1-3. In the Pianoro vineyard in 2006 (Fig. 1A), the warning system provided six alarms based on weather forecasts between 26 April and 6 June. Following these alarms, fungicides were applied on 1 May, 12 May, 29 May, and 9 June in the lowrisk spray program. The first spray, on 1 May, was applied on the fifth day after the alarm because heavy rainfall (43 $\mathrm{mm}$ total) occurred between 27 and 30 April (Fig. 1B), which made spraying impossible. The second spray, on May 12, was applied on the third day after the alarm. The alarm sent on 13 May was disregarded by the vineyard manager because the fungicide application of 12 May already protected plants from this predicted infection. No fungicides were applied in reaction to the alarm sent on 24 May because no manpower was available at that time. The last two sprays were applied in response to the alarms sent on 29 May and 6 June. In the high-risk spray program, no alarms were provided because the ascospore dose estimated by the model was always $<4 \%$ of the seasonal dose; therefore, no fungicides were applied (Table 2). When the disease model was operated using the actual weather data, there were seven predicted infection periods, all of which corresponded to the alarms provided by using the weather forecasts. The powdery mildew symptoms were first observed on 17 May (Fig. 1A).

In the C.S. Pietro vineyard in 2007 (Fig. 2), there were only two alarms based on weather forecasts (30 April and 30 May; Fig. 2A), which resulted in two fungicide applications in the low-risk spray program and one (30 May) in the high-risk spray program (Table 2). On 4 April, even if weather conditions were favorable for infection, the warning system did not provide an alarm because 4 April was too close to bud break (which started on 1 April) and, there-

Table 2. Date of fungicide spray applications and fungicides used in experiments testing the warning system for powdery mildew of grape

\begin{tabular}{|c|c|c|c|c|c|c|c|}
\hline \multirow{2}{*}{$\frac{\text { Experiment, treatment }}{\text { Pianoro } 2006}$} & \multicolumn{7}{|c|}{ Dates of fungicide sprays and fungicides used ${ }^{\mathrm{z}}$} \\
\hline & & & & & & & \\
\hline Low-risk & 1 May E & 12 May E & 29 May E & 9 June A & $\ldots$ & $\ldots$ & $\ldots$ \\
\hline High-risk & & & & & & $\ldots$ & $\ldots$ \\
\hline Grower & 10 May D & 23 May E & 5 June $\mathrm{E}$ & 15 June B & 27 June B & $\ldots$ & $\ldots$ \\
\hline \multicolumn{8}{|l|}{ Tebano 2006} \\
\hline Low-risk & 1 May E & 16 May E & 1 June A & $\ldots$ & $\ldots$ & $\ldots$ & $\ldots$ \\
\hline High-risk & & 16 May E & 1 June A & $\ldots$ & $\ldots$ & $\ldots$ & $\cdots$ \\
\hline Grower & 10 May D & 23 May $\mathrm{E}$ & 5 June E & 15 June B & 27 June B & $\ldots$ & $\ldots$ \\
\hline \multicolumn{8}{|l|}{ Tebano 2007} \\
\hline Low-risk & 30 April E & 30 May G & 8 June $\mathrm{G}$ & $\ldots$ & $\ldots$ & $\ldots$ & $\ldots$ \\
\hline High-risk & 4 May E & 30 May G & $\ldots$ & $\ldots$ & $\ldots$ & $\ldots$ & $\ldots$ \\
\hline Grower & 18 April E & 3 May E & 10 May B & 25 May B & 8 June A & $\ldots$ & $\ldots$ \\
\hline \multicolumn{8}{|l|}{ C.S. Pietro 2007} \\
\hline Low-risk & 30 April E & 30 May G & $\ldots$ & $\ldots$ & $\ldots$ & $\ldots$ & $\ldots$ \\
\hline High-risk & & 30 May E & $\ldots$ & $\ldots$ & $\ldots$ & $\ldots$ & $\ldots$ \\
\hline Grower & 18 April F & 24 April F & 7 May C & 16 May C & 23 May C & 28 May C & 5 June $F$ \\
\hline \multicolumn{8}{|l|}{ Tebano 2008} \\
\hline Low-risk & 14 April E & 22 April E & 29 April G & 23 May G & 4 June A & $\ldots$ & $\ldots$ \\
\hline High-risk & 14 April E & $\ldots$ & 29 April E & $\ldots$ & $\ldots$ & $\ldots$ & $\ldots$ \\
\hline Grower & 17 April C & 30 April E & 14 May E & 26 May B & 9 June B & 20 June $\mathrm{G}$ & $\ldots$ \\
\hline \multicolumn{8}{|l|}{ C.S. Pietro 2008} \\
\hline Low-risk & 14 April E & 22 April E & 19 May G & 04 June G & $\ldots$ & $\ldots$ & $\ldots$ \\
\hline High-risk & & & 19 May E & & & $\ldots$ & $\ldots$ \\
\hline Grower & 24 April C & 30 April C & 9 May C & 22 May C & 31 May F & 9 June F & 15 June F \\
\hline
\end{tabular}

${ }^{y}$ Experiments included an untreated control that was never sprayed.

${ }^{\text {z }}$ Fungicides used were A, Arius; B, Flint; C, Karathane Star; D, Kumulus Tecno; E, Prosper 300 CS; F, Tiovit Jet; and G, Vivando. 
fore, susceptible host tissue was not yet present (4). When the model was operated using the actual weather data, it predicted the occurrence of 10 infection periods, clustered in three groups: 4 April, 2 to 4 May, and 1 to 6 June (Fig. 2A). The disease was first noticed at the beginning of June (Fig. 2A).

In the C.S. Pietro vineyard in 2008 (Fig. 3), the warning system produced eight alarms based on weather forecasts (Fig. 3A). Fungicides were applied four and one times in the low-risk and high-risk spray program, respectively (Table 2). In the low-risk spray program, one alarm (on 30 May) was disregarded because the rain of 29 and 30 May ( $29.5 \mathrm{~mm}$ total rain; Fig. 3B) made it impossible to spray. When the model was operated using actual meteorological data, seven of the eight alarms based on weather forecasts resulted in prediction of infection. The fourth alarm of the season based on forecasts (on 28 April) was unjustified because no infection was predicted when the disease model was operated with actual weather data. Two infection periods (13 and 14 June) were predicted by the model using actual weather data but these had not been predicted by using the weather forecasts. Disease symptoms were first recorded on 9 May in the unsprayed plots.

Considering the six vineyards, 26 alarms were sent in total. Of these, 16 alarms $(62 \%)$ were based on weather forecasts and, therefore, were sent before the predicted infection period; 15 of these alarms $(94 \%)$ were confirmed by running the disease model a posteriori with the actual weather data. Low-risk spray programs started between 10 days earlier (at C.S. Pietro in 2008) and 12 days later (at both vineyards in 2007) than the grower spray program, and they finished earlier, with a maximum difference of 26 days at Tebano in 2006. As a consequence, the time lag between the day when the last spray was applied and the day when disease severity was estimated on bunches was shorter for the grower spray program (average 5 days, maximum 6, minimum 3) than for the lowrisk (average 18 days, maximum 32, minimum 6) and the high-risk (average 32 days, maximum 52, minimum 15, excluding Pianoro in 2006 where no sprays were applied) spray programs.

Powdery mildew control. At Tebano in 2006, the first powdery mildew symptoms appeared on 3 July. At that time, the unsprayed leaves presented $<0.1 \%$ disease severity on average while $20 \%$ of the unsprayed bunches were diseased with approximately $1 \%$ of severity (Table 3 ). Five applications were performed following the grower's schedule, and neither leaves nor bunches were affected by powdery mildew. The same results were obtained following the disease warning system, with only three and two sprays in the lowrisk and high-risk spray programs, respectively.

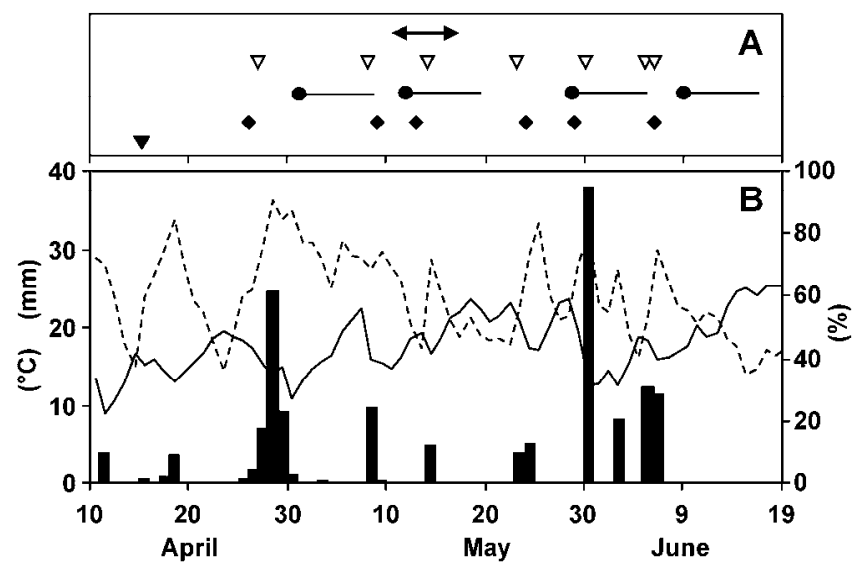

Fig. 1. Example of the Pianoro vineyard in 2006 , showing $A$, alarms provided by the warning system operated using 72 -h weather forecasts $(\bullet)$, time when fungicides were applied in the low-risk spray program (-), estimated period of protectant activity of any fungicide application (solid line), date of grapevine bud break $(\boldsymbol{\nabla})$, prediction of infection $(\nabla)$ produced by the model operated using actual weather data, and first disease onset in the vineyard $(\leftrightarrow)$; and $\mathbf{B}$, the measured temperature (solid line),relative humidity (---), and rainfall (bars).
The results at Tebano in 2007 were similar to those of 2006. The disease appeared in mid-June on both leaves and bunches at very low level; average disease severity on bunches was $0.004 \%$ of surface area. Five, three, and two sprays were applied in the grower, low-risk, and high-risk spray programs, respectively, which were all disease free at mid-June, when berries were $4 \mathrm{~mm}$ in diameter (Table 3 ). The same pattern occurred in the C.S. Pietro vineyard in 2007. The disease appeared on 8 June on $30 \%$ of the unsprayed bunches, with an average disease severity of $0.8 \%$. The grower, low-risk, and high-risk spray programs called for seven, two, and one sprays, respectively, and they were all nearly disease free (Table 3).

At Tebano in 2008, powdery mildew appeared on leaves in the unsprayed plots at the end of May. On 23 June, disease severity on leaves was $5.5 \%$ (with $50 \%$ incidence); on the same date, $29 \%$ of bunches were diseased, with severity of $0.7 \%$. Six, five, and two sprays were applied in the grower, low-risk, and high-risk spray programs, respectively, which all were disease free or showed only disease traces on 23 June (Table 3).

The results at C.S. Pietro in 2008 were similar to those of Tebano in the same year but the disease severity on the unsprayed

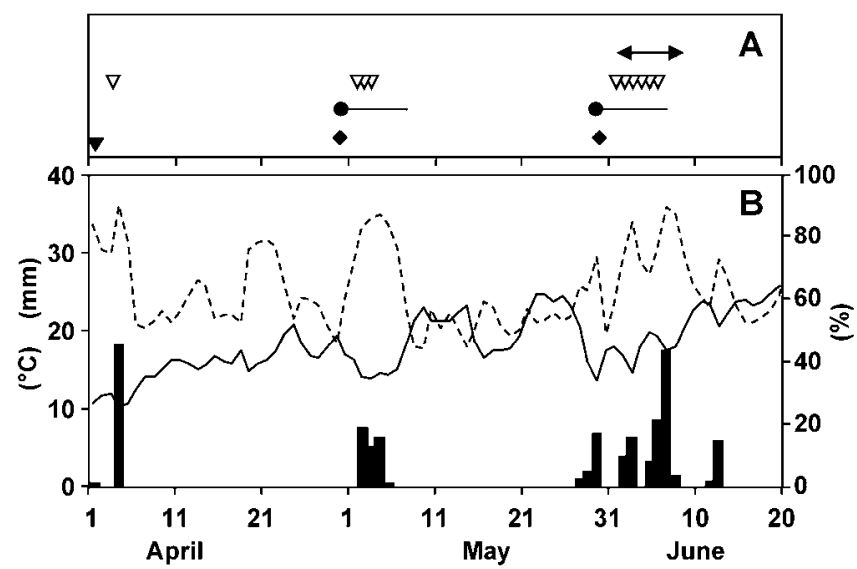

Fig. 2. Example of the C.S. Pietro vineyard in 2007, showing A, alarms provided by the warning system operated using $72-h$ weather forecasts $(\bullet)$, time when fungicides were applied in the low-risk spray program $(\mathbf{0})$, estimated period of protectant activity of any fungicide application (solid line), date of grapevine bud break $(\boldsymbol{\nabla})$, prediction of infection $(\nabla)$ produced by the model operated using actual weather data, and first disease onset in the vineyard $(\leftrightarrow)$; and $\mathbf{B}$, the measured temperature (solid line), relative humidity (---), and rainfall (bars).

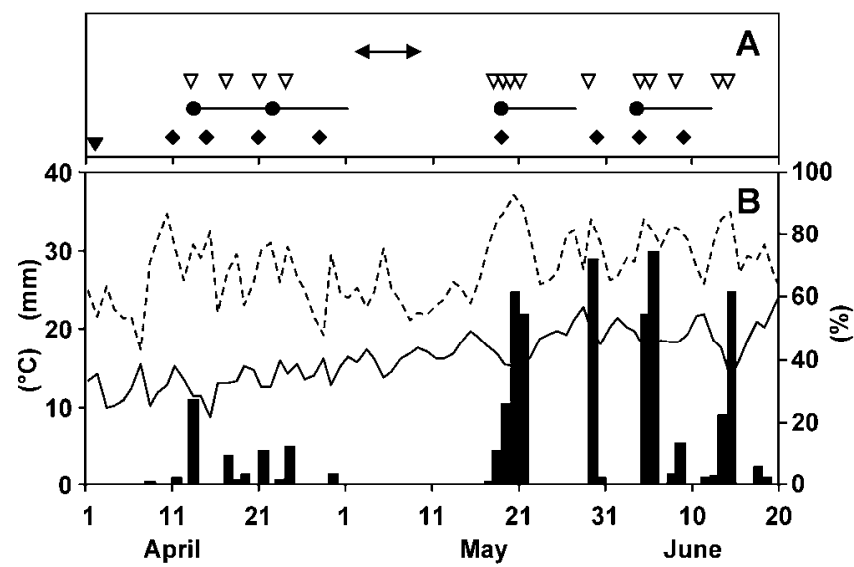

Fig. 3. Example of the C.S. Pietro vineyard in 2008 , showing $\mathbf{A}$, alarms provided by the warning system operated using $72-h$ weather forecasts $(\bullet)$, time when fungicides were applied in the low-risk spray program (0), estimated period of protectant activity of any fungicide application (solid line),date of grapevine bud break $(\boldsymbol{\nabla})$, prediction of infection $(\nabla)$ produced by the model operated using actual weather data, and first disease onset in the vineyard $(\leftrightarrow)$; and $\mathbf{B}$, the measured temperature (solid line),relative humidity (---), and rainfall (bars). 
bunches was higher (20.9\% of the bunch surface diseased). In the high-risk spray program, disease severity was lower than in the untreated plots (1.6\% of bunch surface diseased) but it was higher than in the low-risk and grower spray programs, where the disease was present with $\leq 1 \%$ of severity (Table 3 ). Seven, four, and one sprays were applied in the grower, low-risk, and high-risk spray programs, respectively.

In the Pianoro vineyard in 2006, disease pressure was extremely high. The first symptoms appeared on 17 May, and the disease rapidly increased until $100 \%$ of the leaves and $100 \%$ of the bunches were diseased on 15 June and 3 July, respectively, in the unsprayed plots, with average disease severity of $64.5 \%$ on leaves and of $75.0 \%$ on bunches (Table 3). The five fungicide sprays applied in the grower treatment reduced the disease severity to $1.5 \%$ on leaves and to $7.0 \%$ on bunches. Disease levels did not significantly differ in the grower and low-risk spray programs, even though the low-risk spray program called for one fewer spray. In the high-risk treatment, fungicides were not applied because none of the predicted infection periods had $>4 \%$ of the seasonal ascospore dose; therefore, the disease was similar to that of the untreated plots.

Efficacy and costs of fungicide treatments. Compared with the unsprayed control, the three spray programs reduced disease severity on both leaves and bunches in all the vineyards, except for the high-risk spray program at Pianoro in 2006 (Table 3). The six field experiments were performed under a range of conditions, including different years, cultivars, and locations. Efficacy in suppressing disease severity ranged from $6 \%$ (for the high-risk treatment in
Pianoro vineyard in 2006) to about $100 \%$ (for all the grower treatments, with the exception of Pianoro in 2006, where efficacy was $91 \%$ ). Average efficacy in suppressing disease on leaves was about $100,92.4$, and $73.3 \%$ in the grower, low-risk, and high-risk spray programs, respectively. On bunches, average efficacy for the three spray programs was $98.4,95.9$, and $78.4 \%$, respectively.

Compared with the average number of fungicide sprays in the grower spray program (5.7 sprays on average per year), the number of sprays was reduced by $36 \%$ in the low-risk spray program (3.5 sprays) and by $75 \%$ in the high-risk spray program (1.3 sprays). Spray reduction was greater when the environmental conditions were unfavorable for E. necator (as at C.S. Pietro in 2007, where the warning system recommended five fewer sprays than the grower spray program) than when there were severe epidemics (as at Pianoro in 2006, where the warning system recommended one fewer spray than the grower spray program).

The grower spray program was the most expensive control strategy, averaging $221 € / \mathrm{ha} /$ year, with a minimum of $197 € /$ ha in the Pianoro vineyard in 2006 and a maximum of $251 € /$ ha in the Tebano vineyard in 2008. The grower spray program did not change according to the disease level: for instance, in the C.S. Pietro vineyard, the cost was equal in 2007 ( $231 € /$ ha), when there was low level of disease, and in 2008, when the disease was severe. The two spray programs based on the disease warnings were less costly, averaging $165 € /$ ha/year (115 to $238 € /$ ha/year) for the low-risk spray program and $60 € /$ ha/year ( 0 to $95 € /$ ha/year) for the highrisk spray program. The average saving was 56 and $161 € /$ ha/year for the two spray programs, respectively, with the highest saving of

Table 3. Number of fungicide sprays and disease severity for leaves and bunches in different growth stages in experiments testing the warning system for powdery mildew of grape

\begin{tabular}{|c|c|c|c|c|c|}
\hline \multirow[b]{2}{*}{ Experiment, spray program ${ }^{y}$} & \multirow[b]{2}{*}{ Sprays $^{\mathrm{z}}$} & \multicolumn{4}{|c|}{ Disease severity $(\%)^{x}$} \\
\hline & & & Leaves & & Bunches \\
\hline Pianoro 2006 & & 5 June (20) & 15 June (26) & 3 July (29) & 3 July (29) \\
\hline Unsprayed & - & $28.4 \mathrm{a}$ & $64.5 \mathrm{a}$ & - & $75.0 \mathrm{a}$ \\
\hline Low-risk & 4 & $1.3 \mathrm{~b}$ & $2.3 \mathrm{~b}$ & - & $16.2 \mathrm{~b}$ \\
\hline High-risk & 0 & $17.9 \mathrm{ab}$ & $25.8 \mathrm{ab}$ & - & $70.9 \mathrm{a}$ \\
\hline Grower & 5 & $0 \mathrm{~b}$ & $1.5 \mathrm{~b}$ & - & $7.0 \mathrm{~b}$ \\
\hline Tebano 2006 & & 29 May (20) & 15 June (26) & 3 July (29) & 3 July (29) \\
\hline Unsprayed & - & 0 & 0 & $\operatorname{tr}$ & $0.2 \mathrm{a}$ \\
\hline Low-risk & 3 & 0 & 0 & 0 & $0 \mathrm{~b}$ \\
\hline High-risk & 2 & 0 & 0 & 0 & $0 \mathrm{~b}$ \\
\hline Grower & 5 & 0 & 0 & 0 & $0 \mathrm{~b}$ \\
\hline Tebano 2007 & & 30 May (20) & 8 June (27) & 14 June (29) & 14 June (29) \\
\hline Unsprayed & - & 0 & 0 & $\operatorname{tr}$ & $\operatorname{tr}$ \\
\hline Low-risk & 3 & 0 & 0 & 0 & 0 \\
\hline High-risk & 2 & 0 & 0 & 0 & 0 \\
\hline Grower & 5 & 0 & 0 & 0 & 0 \\
\hline C.S. Pietro 2007 & & 21 May (19) & 31 May (26) & 8 June (29) & 8 June (29) \\
\hline Unsprayed & - & 0 & 0 & 0.2 & $0.8 \mathrm{a}$ \\
\hline Low-risk & 2 & 0 & 0 & 0 & $0 \mathrm{~b}$ \\
\hline High-risk & 1 & 0 & 0 & 0 & $\operatorname{tr} b$ \\
\hline Grower & 7 & 0 & 0 & 0 & $0 \mathrm{~b}$ \\
\hline Tebano 2008 & & 6 June (19) & 13 June (26) & 23 June (31) & 23 June (31) \\
\hline Unsprayed & - & $0.1 \mathrm{a}$ & $1.6 \mathrm{a}$ & $5.5 \mathrm{a}$ & $0.7 \mathrm{a}$ \\
\hline Low-risk & 5 & $0 \mathrm{~b}$ & $0 \mathrm{~b}$ & $0.1 \mathrm{~b}$ & $0 \mathrm{~b}$ \\
\hline High-risk & 2 & $0 \mathrm{~b}$ & $0 \mathrm{~b}$ & $0.4 \mathrm{~b}$ & $\operatorname{tr} b$ \\
\hline Grower & 6 & $0 \mathrm{~b}$ & $0 \mathrm{~b}$ & $0.1 \mathrm{~b}$ & $0 \mathrm{~b}$ \\
\hline C.S. Pietro 2008 & & 6 June (19) & 13 June (26) & 20 June (31) & 20 June (31) \\
\hline Unsprayed & - & $0.8 \mathrm{a}$ & $1.2 \mathrm{a}$ & $10.9 \mathrm{a}$ & $20.9 \mathrm{a}$ \\
\hline Low-risk & 4 & $0.2 \mathrm{~b}$ & $0.3 \mathrm{~b}$ & $1.1 \mathrm{~b}$ & $0.1 \mathrm{c}$ \\
\hline High-risk & 1 & $0.3 \mathrm{~b}$ & $0.8 \mathrm{ab}$ & $1.7 \mathrm{~b}$ & $1.6 \mathrm{~b}$ \\
\hline Grower & 7 & $\operatorname{tr} b$ & $0.1 \mathrm{~b}$ & $0.8 \mathrm{~b}$ & $\operatorname{tr} \mathrm{c}$ \\
\hline
\end{tabular}

${ }^{x}$ Disease severity as a percentage of leaf or bunch surface with powdery mildew (calculated on 100 random leaves or bunches per plot, four replicate plots per treatment); $\operatorname{tr}<0.1 \%$. Sampling dates and, in parentheses, corresponding growth stages of the modified Eichhorn-Lorenz system (Coombe, 1995) are as follows: 19 = beginning of flowering; $20=10 \%$ caps off; $26=$ cape-fall complete; $27=$ setting; $29=$ berries $4 \mathrm{~mm}$ in diameter; and $31=$ berries $7 \mathrm{~mm}$ in diameter. Values followed by the same letter are not significantly different at $P=0.05$ based on Fisher's protected least square difference test; - indicates that data were not collected.

${ }^{y}$ Spray programs consisted of different fungicide schedules: unsprayed; low-risk = spraying when the warning system indicated that an infection period was predicted (or calculated a posteriori) and at least 7 days had elapsed since the previous fungicide application; high-risk $=$ spraying when an infection period was predicted (or calculated a posteriori) that involved at least $4 \%$ of the seasonal ascospore dose; grower $=$ sprayed according the grower's schedule.

${ }^{\mathrm{z}}$ Number of sprays. Dates of the sprays are listed in Table 2. 
$183 € /$ ha for the high-risk spray program in the C.S. Pietro vineyard in 2007, when the disease developed in traces.

The warning system had no economic impact on the market value of the product because bunch damage levels were similar in the three spray programs (low-risk, high-risk, and grower), except at Pianoro in 2006 (Table 3).

\section{Discussion}

Results from the present work strongly support the importance of early-season powdery mildew control $(22,32)$. When no flag shoots are present, as in the vineyards studied here, a disease control strategy aimed at controlling the ascosporic infections early in the season maintained the disease at a very low level during flowering and early berry formation, which is the period when bunches are most susceptible to the disease (18).

The warning system uses a model that predicts primary infection periods during the ascosporic inoculum season. Advisories were then produced to protect vines from primary infections, while possible secondary infections were disregarded. Nevertheless, the disease was effectively managed. There are two main reasons to target early-season spray programs against ascosporic infections, disregarding conidial infections. The first reason is that effective suppression of primary powdery mildew infections may prevent or reduce the production of conidia (24). The second reason is that conidia usually appear later in the season. Carisse et al. (10) showed that conidia are first present in the vineyard when approximately 500 to 600 degree-days (base $6^{\circ} \mathrm{C}$ ) accumulated after the "two to three leaves unfolded" growth stage. In the six vineyards studied here, this degree-day level occurred between 26 May and 15 June, which is when the primary inoculum season ended.

The current study provides substantial evidence that the warning system can be used to time fungicide sprays for early management of powdery mildew in northern Italy. If the disease model predicts the presence of mature ascospores and if suitable conditions for ascospore release and infection are forecast, then a protectant fungicide can be applied in advance of the potential infection period. However, if the model predicts the absence of mature ascospores or if no rain is forecast, the grower can wait for the model to evaluate a likely infection period. Then, if the model indicates that infection was likely in the previous day, a fungicide with postinfection activity could be applied soon (14).

The present work also demonstrates that powdery mildew of grape in northern Italy could be controlled effectively with fewer fungicide applications in the early season than the grower's standard schedule by use of the warning system. Interestingly, spray reduction was greater when powdery mildew caused minor epidemics until early berry development (as in four vineyards of this study) than when there were severe epidemics early in the season (as in two vineyards of this study). Therefore, use of the warning system could have relevant impact on fungicide use in northern Italy and other viticultural areas where the logarithmic phase of the powdery mildew epidemics often starts during bunch closure and continues until ripening $(33,36,43)$. Further evaluation of the warning system under severe powdery mildew epidemics is necessary.

The reduction in fungicide use would probably result in fewer chemical residues on produce consumed by a health-conscious public (25). In addition, the warning system can save growers in the cost of fungicide applications. Environmental benefits should also be considered. Each saved application represents a reduction of 4.9 liters/ha in fuel consumption and a related reduction of about $12.5 \mathrm{~kg} / \mathrm{ha}$ of $\mathrm{CO}_{2}$ emissions (34).

In the warning system, use of the weather forecasts made it possible to predict powdery mildew infection periods in advance. In a previous work on grapevine downy mildew (3), inaccuracy of the weather forecasts caused unjustified sprays. Inaccuracy of weather forecasts is a well-known factor affecting the accuracy of disease warning systems $(1,29,44,49)$. In the current study, most (94\%) of the alarms provided by the powdery mildew model based on the weather forecasts were confirmed by running the model with the actual weather data. Moreover, about one-third of the total alarms in the current study were based on actual weather data (i.e., after infection had occurred), alarms that were not previously detected by using the weather forecasts. The latter inaccuracy of the weather forecasts may have no impact on powdery mildew control because most of the fungicides have post-infection activity due to the epiphytic growth of E. necator colonies (14).

Any weather-based fungicide program must meet several criteria before being accepted by growers. First, growers must have trust that risks of crop damage associated with reliance on such an approach are minimal. Better disease control is the main factor that causes Californian grape growers to accept the powdery mildew forecasts provided by the UC Davis Risk Assessment Model (30). Users of this model also cite chemical savings as a motivation for model use, as well as reduced chemical costs. Based on disease data from test plots in the current study, it appears that the use of the weather-based system can substantially reduce spray frequency and cost without compromising crop health and, consequently, yield and quality.

We suggest that, regardless of their tolerance of risk, growers can benefit from the warning system. For the purpose of discussion, let us categorize growers into three groups with respect to risk tolerance: those growers who want minimal risk, those who will accept a low level of risk, and those who will accept a higher level of risk (30). Growers in the first group will prefer to routinely apply fungicides at short intervals rather than risk making a mistake using a warning system. These growers can benefit from the warning system because the system can help them decide whether to spray with a fungicide with pre- or post-infection activity (14), or whether an additional spray is needed when the disease model indicates that weather conditions have been favorable for powdery mildew infection. The second group of growers can benefit from the warning system by spraying fungicides whenever the disease model predicts an infection period; in this way, they can reduce fungicide application and save money without risking insufficient disease control. The growers in the third group can apply fungicides only when severe infections are forecast; these growers benefit because they can more intensively reduce fungicide application and costs. Growers in the third group, however, risk insufficient powdery mildew control when the disease pressure is high. These growers should be cautious in vineyards where powdery mildew has previously been a problem and that, therefore, probably contain high levels of chasmothecia next season $(32,42)$.

Another important criterion for grower adoption of the warning system is that the warning services must be affordable. In some Italian grape-growing areas, warning services are freely supplied by governmental plant protection organizations (40). Therefore, there are no direct costs for the weather-sensing equipment and the accompanying software. The only costs the grower incurs is for an internet connection or a mobile phone for receiving SMSs. It is unlikely that these costs will deter growers from using this technology.

Finally, ease of use is also critical for grower acceptance of a weather-based warning system for powdery mildew control. The warning system described in this study is easy to use because it provides a clear decision support: the infection is either predicted or not. Growers do not necessarily need to look at the raw data or calculate and interpret disease risk indexes to use the system.

\section{Acknowledgments}

S. E. Legler carried out this work within the Doctoral School on the AgroFood System (Agrisystem) of the Università Cattolica del Sacro Cuore (Italy). We thank G. Pradolesi and M. Scannavini for managing the experimental vineyards and M. G. Tommasini for coordinating the research project, which was funded by the Emilia-Romagna Region.

\section{Literature Cited}

1. Beresford, R. M., and Spink, M. 1992. A national disease forecasting system for apple black spot (Venturia inaequalis) in New Zealand. Acta Hortic. 313:285-296.

2. Bertocchi, D., Cattaneo, L., Pizzati, C., and Cortesi, P. 2010. Protection of grapevine against powdery mildew with fungicides applied at increasing disease incidence thresholds. Atti Giornate Fitopatol. 2:305-310. 
3. Caffi, T., Rossi, V., and Bugiani, R. 2010. Evaluation of a warning system for controlling primary infections of grapevine downy mildew. Plant Dis. 94:709-716.

4. Caffi, T., Rossi, V., Legler, S. E., and Bugiani, R. 2011. A mechanistic model simulating ascosporic infections by Erysiphe necator, the powdery mildew fungus of grapevine. Plant Pathol. 60:522-531.

5. Calonnec, A., Cartolaro, P., Deliere, L., and Chadoeuf, J. 2006. Powdery mildew on grapevine: the date of primary contamination affects disease development on leaves and damage on grape. Bull. OILB/SROP 29:67-73.

6. Calonnec, A., Cartolaro, P., Poupot, C., Dubourdieu, D., and Darriet, P. 2004. Effects of Uncinula necator on the yield and quality of grapes (Vitis vinifera) and wine. Plant Pathol. 53:434-445.

7. Campbell, C. L., and Madden, L. V. 1990. Introduction to Plant Disease Epidemiology. Wiley, NewYork.

8. Carisse, O. 2009. Gestion raisonnée des principales maladies de la vigne au Québec. Publication d'AAC 10372F.

9. Carisse, O., Bacon, R., and Lefebvre, A. 2009. Grape powdery mildew (Erysiphe necator) risk assessment based on airborne conidium concentration. Crop Prot. 28:1036-1044.

10. Carisse, O., Bacon, R., Lefebvre, A., and Lessard, K. 2009. A degree-day model to initiate fungicide spray programs for management of grape powdery mildew (Erysiphe necator). Can. J. Plant Pathol. 31:186-194.

11. Chellemi, D. O., and Marois, J. J. 1991. Sporulation of Uncinula necator on grape leaves as influenced by temperature and cultivar. Phytopathology $81: 197-201$.

12. Coombe, B. G. 1995. Adoption of a system for identifying grapevine growth stages. Aust. J Grape Wine Res 1:104-110.

13. Cortesi, P., Bisiach, M., Ricciolini, M., and Gadoury, D. M. 1997. Cleistothecia of Uncinula necator-an additional source of inoculum in Italian vineyards. Plant Dis. 81:922-926.

14. Deliere, L., Miclot, A., Suris, P., Rey, P., and Calonnec, A. 2010. Efficacy of fungicides with various modes of action in controlling the early stages of an Erysiphe necator-induced epidemic. Pest Manage. Sci. 66:1367-1373.

15. Dent, D. 1995. Integrated Pest Management. Chapman \& Halt, London.

16. Gadoury, D. M., and Pearson, R. C. 1988. Initiation, development, dispersal, and survival of cleistothecia of Uncinula necator in New York vineyards. Phytopathology 78:1413-1421.

17. Gadoury, D. M., Seem, R. C., Magarey, P. A., Emmett, R., and Magarey, R. 1997. Effects of environment and fungicides on epidemics of grape powdery mildew: considerations for practical model development and disease management. Vitic. Enol. Sci. 52:225-229.

18. Gadoury, D. M., Seem, R. C., Ficke, A., and Wilcox, W. F. 2003. Ontogenic resistance to powdery mildew in grape berries. Phytopathology 93:547-555.

19. Gadoury, D. M., Seem, R. C., Pearson, R. C., Wilcox, W. F., and Dunst, R. M. 2001. Effects of powdery mildew on vine growth, yield, and quality of Concord grapes. Plant Dis. 85:137-140.

20. Gubler, W. D., Rademacher, M. R., Vasquez, S. J., and Thomas, C. S. 1999. Control of powdery mildew using the UC Davis powdery mildew risk index. Online publication. doi:10.1094/apsnetfeature-1999-0199.

21. Gubler, W. D., Smith, R. J., Varela, L. G., Vasquez, S., Stapleton, J. J., Purcell, A. H., and Leavitt, G. M. 2006. UC IPM Pest management guidelines: grape powdery mildew. Univ. Calif. ANR Publ. No. 3448.

22. Gubler, W. D., and Thomas, C. S. 2006. Control of grapevine powdery mildew: timing of fungicide applications by use of the U C Davis Risk Assessment Model. (Abstr.) Phytopathology 96:S168.

23. Halleen, F., and Holz, G. 2000. Cleistothecia and flag shoots: sources of primary inoculum for grape powdery mildew in the Western Cape province, South Africa. South African J. Enol. Vitic. 21:66-70.

24. Hartman, J., and Beale, J. 2008. Powdery mildew of grape. Plant pathology fact sheet. Univ. Ky. Coop. Ext. Serv. Publ. No. PPFS-FR-S-12.

25. Hill, G. K. 1990. Plasmopara Risk Oppenheim-a deterministic computer model for the viticultural extension service. Not. Mal. Piante 111:231.

26. Hoffmann, P., and Viranyi, F. 2007. The occurrence of cleistothecia of Erysiphe necator (grapevine powdery mildew) and their epidemiological significance in some vine-growing regions of Hungary. Acta Phytopathol. Entomol. Hung. 42:9-16.

27. Jailloux, F., Willocquet, L., Chapuis, L., and Froidefond, G. 1999. Effect of weather factors on the release of ascospores of Uncinula necator, the cause of grape powdery mildew, in the Bordeaux region. Can. J. Bot. 77:10441051.

28. Kast, W. K. 1997. A step by step risk analysis (SRA) used for planning sprays against powdery mildew (OiDiag-System). Vitic. Enol. Sci. 52:230321.

29. Krause, R. A., and Massie, L. B. 1975. Predictive systems: modern approaches to disease control. Annu. Rev. Phytopathol. 13:31-47.

30. Lybbert, T. J., and Gubler, W. D. 2008. California wine grape growers' use of powdery mildew forecasts. Agric. Resour. Econ. Update 11:11-14.

31. Magarey, P. A. 2010. Managing powdery mildew. Fact Sheet GWRDC Innovators Network.

32. Magarey, P. A., Magarey, R. D., and Emmett, R. W. 2000. Principles for managing the foliage diseases of grapevine with low input of pesticides. Pages 140-148 in: Proc. 6th Int. Congr. Org. Vitic. H. Willer and U. and Meier, ed. Basel, Switzerland.

33. Magarey, P. A., and Moyer, M. M. 2010. Toward establishing low input regimes in Australian viticulture 3: use of "epi-season" and "lag phase control" in applying epidemiological knowledge of grapevine powdery mildew, to reduce the number of sprays and inoculum reservoirs for long-term control. Pages 114-116 in: Proc. 6th Int. Workshop Grapevine Downy and Powdery Mildew. A. Calonnec, F. Delmotte, B. Emmet, D. Gadoury, C. Gessler, D. Gubler, H. H. Kassemeyer, P. Magarey, M. Raynal, and R. Seem, eds. Bordeaux, France.

34. Massetti, L., Dalla Marta, A., and Orlandini, S. 2008. Preliminary economic evaluation of an agrometeorological system for Plasmopara viticola infections management. Acta Hortic. 803:43-50.

35. Mills, W. D., and La Plante, A. A. 1951. Diseases and insects in the orchard. Cornell Ext. Bull. 711.

36. Moyer, M. M., Gadoury, D. M., Cadle-Davidson, L., Dry, I. B., Magarey, P. A., Wilcox, W. F., and Seem, R. C. 2010. Effects of acute low-temperature events on development of Erysiphe necator and susceptibility of Vitis vinifera. Phytopathology 100:1240-1249.

37. Pavan, V., Tomozeiu, R., Salvini, A., Marchesi, S., and Marsigli, C. 2003. Controllo di qualità dei dati giornalieri di temperatura minima e massima e di precipitazione. Quad. Tec. ARPA-SIM 15:1-10.

38. Pearson, R. C., and Gadoury, D. M. 1987. Cleistothecia, the source of primary inoculum for grape powdery mildew in New York. Phytopathology 77:1509-1514.

39. Pool, R. M., Pearson, R. C., Welser, M. J., Lakso, A. N., and Seem, R. C. 1984. Influence of powdery mildew on yield and growth of Rosette grapevines. Plant Dis. 68:590-593.

40. Rosa, M., Genesio, R., Gozzini, B., Maracchi, G., and Orlandini, S. 1993. Plasmo: a computer program for grapevine downy mildew development forecast. Comput. Electron. Agric. 9:205-215.

41. Rossi, V., Caffi, T., and Legler, S. E. 2010. Dynamics of ascospore maturation and discharge in Erysiphe necator, the causal agent of grape powdery mildew. Phytopathology 100:1321-1329.

42. Rossi, V., Caffi, T., Legler, S. E., Bugiani, R., and Frisullo, P. 2011. Dispersal of the sexual stage of Erysiphe necator in northern Italy. IOBC Bull 66:115-121.

43. Rossi, V., Caffi, T., Meandri, M., and Pradolesi, G. 2006. Aggiornamenti sul mal bianco della vite. Agronomica 2:32-48.

44. Rumbou, A., and Gessler, C. 2006. Particular structure of Plasmopara viticola populations evolved under Greek island conditions. Phytopathology 96:501-509

45. Sall, M. A., Wrysinski, J., and Schick, F. J. 1983. Temperature-based sulfur applications to control grape powdery mildew. Calif. Agric. 37:4-5.

46. Sozzani, F., Morando, A., and Lavezzaro, S. 2010. Grapevine protection against powdery mildew in Piedmont: control of on-going infections. Atti Giornate Fitopatol. 2:311-316

47. Steppeler, J., Doms, G., Schättler, U., Bitzer, H. W., Gassmann, A., Damrath, U., and Gregoric, G. 2003. Meso-gamma scale forecasts using the nonhydrostaticmodel LM. Meteorol. Atmos. 115:488-504.

48. Thomas, C. S., Gubler, W. D., and Leavitt, G. 1994. Field testing of a powdery mildew disease forecast model on grapes in California. (Abstr.) Phytopathology 84:1070

49. Vercesi, A., Zerbetto, F., and Rho, G. 1999. Impiego dei modelli EPI e PRO nella difesa antiperonosporica del vigneto. Frustula Entomol. 22:92-97. 